E Nature and Space

\title{
Risk capital: Urban political ecology and entanglements of financial and environmental risk in Washington, D.C.
}

Environment and Planning E: Nature and

Space

2018, Vol. I(I-2) I44-I64

(C) The Author(s) 2018

Reprints and permissions: sagepub.co.uk/journalsPermissions.nav DOI: $10.1|77 / 25| 48486 \mid 8770369$ journals.sagepub.com/home/ene

@SAGE

\section{Brett Christophers}

Uppsala University, Sweden

\begin{abstract}
In endeavouring to deal with a longstanding problem of contamination of waterways in Washington, D.C. due to combined sewer overflows, the responsible utility, DC Water, has recently embarked on a two-fold, simultaneous 'greening' - firstly of the physical infrastructures being installed to address the overflow problem, and secondly of the financing of this capital investment. This article examines DC Water's turn to green infrastructure and green bonds in order to consider the question of how environmental and financial processes in general - and environmental and financial risks in particular - co-determine not just one another but the transformation of contemporary urban socioecological landscapes more broadly. In the process, it aims to inject a greater sensibility both to finance and to 'green capitalism' into urban political ecology. Through a critical consideration of the interlocking temporal, spatial and monetary dimensions of DC Water's two-fold greening project, the article shows that this project has served significantly to augment levels of environmental and financial risk, entangling them in significant new ways.
\end{abstract}

\section{Keywords}

Green infrastructure, green bonds, combined sewer overflows, risk, urban political ecology

\section{Introduction}

Investments in bottled water companies, speculation in water-industry related financial instruments and global/local hydrological cycles fuse together in the production of hybridized waters and cyborg cities. (Swyngedouw, 1996: 80)

For the past two decades, the field of urban political ecology (UPE) has been at the forefront of critical investigations into the intersections of nature and (city) space. It provides, two leading protagonists say, 'an integrated and relational approach that helps untangle the interconnected economic, political, social and ecological processes that together go to

\section{Corresponding author:}

Brett Christophers, Department of Social and Economic Geography, Uppsala University, PO Box 513, Uppsala 75I20, Sweden.

Email: brett.christophers@kultgeog.uu.se 
form highly uneven urban landscapes' (Swyngedouw and Heynen, 2003: 914). More specifically, two decades of UPE scholarship have illustrated 'the myriad articulations of how urban environmental and social change co-determine each other' (Heynen, 2014: 598). Over the same period, meanwhile, social processes in general, and urban social processes in particular, have increasingly come to be shaped by financial markets, motives and institutions: they have, in a word, been financialized (Fields, 2017; Halbert and Attuyer, 2016). Yet, isolated gestures toward the significance of finance - such as Erik Swyngedouw's in the above epigraph - notwithstanding, financial processes have been conspicuously absent from the array of social processes whose co-determination of and by environmental processes UPE examines. ${ }^{1}$

This article proceeds from the premise that in an age of urban financialization, this lacuna is not just problematic, but untenable. The goal of the article therefore is to explore how UPE might begin to address it. How can finance be brought meaningfully 'into' UPE? Doubtless this can and should be done in a variety of different ways. But the particular approach taken in this article is to focus on questions of risk. If, pace Heynen, UPE is most interested in demonstrating the co-determination of environmental and social change in the shaping of urban landscapes, how, specifically, do environmental and financial risks codetermine one another, and with what consequences for the urban socioecological landscapes within which those risks materialize? In posing these questions, the article understands environmental and financial risk as actual or potential threats to, respectively, environmental and financial well-being.

In pursuing this approach, the article draws on the work of scholars in fields other than UPE in examining the relationships between environmental and financial risks. On the one hand, it has been widely demonstrated that environmental risks of various kinds shape indeed, constitute - financial risks. An obvious example is the financial risk to property represented by exposure to geophysical, biological, and meteorological catastrophic events exposure that is typically managed through a range of insurance and reinsurance mechanisms (Johnson, 2013). On the other hand, it has been shown that the obverse also applies: financial risks shape environmental risks. Biodiversity loss, air and water pollution, flooding and a host of other environmental risks are all fashioned to one degree or another by their particular historical-geographical financial contexts (e.g. Cutter and Emrich, 2006; Shandra et al., 2010). As Cutter and Emrich (2006) have shown, for instance, the availability and cost of flood insurance demonstrably influence flood risk insofar as they shape society's incentives to implement flood mitigation measures. In the literatures in question, however, the focus is typically on just one direction of determination - that is, the influence of the financial on the environmental, or vice versa. From UPE, the present article takes the signal imperative to attend to processes of $c o$-determination. Urban landscapes are sculpted by the reciprocal relations between environmental and social (here, financial) processes.

The article develops this conceptual argument through an empirical examination of one city, the US capital Washington, D.C., and one of UPE's longstanding stocks in trade, water. Washington's sewer system includes vast tracts of so-called combined sewers, which use a single pipe to convey waste and storm water. The capacity of the city's combined sewer system (CSS), which serves around one-third of the District, to remove pollutants from sewage before safely discharging it into local waterways is frequently exceeded, especially during periods of heavy rainfall. When this occurs, those waterways - the Potomac and Anacostia Rivers and Rock Creek - receive untreated excess: 'combined sewer overflows' (CSO). Discharged via some 47 outfalls across the capital region and widely recognized to be severely detrimental to the aquatic environment and to human health (e.g. Buerger, 2012; 
EPA, 2014: 5-6), DC's CSOs continue to run into the billions of gallons in a typical year (DC Water, 2015a).

The body responsible for providing D.C. with clean water and with sewage collection and treatment is the District of Columbia Water and Sewer Authority, which has operated since 2010 as DC Water. An independent authority of the District of Columbia, DC Water was established in 1996 by the District Government - from whom it took over water and sewage services - and the federal government. The capital's CSO problems have been a prominent local issue ever since DC Water's inception. 2004 and 2005 were landmark years in the protracted, ongoing process of DC Water addressing and ultimately attempting to resolve these problems. In 2004, its Long-Term CSO Control Plan (LTCP) (DC Water, 2002), a requirement of the Environmental Protection Agency's (EPA) 1994 CSO Control Policy, was approved by the latter. In 2005, DC Water entered into a Consent Decree with the EPA and the Department of Justice (DOJ) that bound it to implementation of its LTCP, subsequently renamed the DC Clean Rivers Project, according to a fixed schedule (EPA, 2005).

Around a decade later, DC Water embarked on a high-profile, two-fold 'greening' of the Clean Rivers Project, in an example of the wider ongoing urbanization of 'green capitalism' across the United States (Knuth, 2016). First, it began to shift substantially from 'grey' to 'green infrastructure'. To that point, the infrastructural technology involved in the CSO clean-up had been primarily grey (e.g. pipes, pumps, tanks and tunnels), that is, humanengineered; henceforth, it would involve a sizable green component (e.g. green roofs and rain gardens), which entails harnessing 'nature' in the service of its protection. ${ }^{2}$ Second, DC Water shifted substantially from grey - or, in industry parlance, 'vanilla' - to green financing. This occurred in its use of the municipal debt markets, the growth of which has been pivotal to the financialization of US cities and city governments in recent decades (Sbragia, 1996). In 2014, DC Water issued its first 'green bond', worth \$350m, to finance a portion of the Clean Rivers Project. $\$ 225 \mathrm{~m}$ of additional green bonds have followed, including, in September 2016, a much-discussed \$25m 'Environmental Impact Bond' (EIB) that links the level of return payable to investors in the bond to the degree of DC Water's success in reducing CSOs - the nation's (and perhaps world's) first example of 'Pay for Success' financing in an environmental rather than social context. This two-fold greening is the focus of the article, which thus responds to Knuth's call for scholars to 'do more to follow green capitalism's drives into cities and other unconventional second natures' (2016: 628).

The article submits that DC Water's newly, doubly 'greened' strategy for implementing and financing CSO reduction, one actively abetted by the EPA and DOJ, has constituted put in place - a noxious constellation of amplified and entangled environmental and financial risks, for all the surface ('green') appearances to the contrary. It further argues that the crystallization of these risks is likely to have deleterious consequences particularly for local residents, who are the ultimate social bearers of those risks both as inhabitants of the environment and, through the payment of DC Water's fees and charges, as the principal funders of the latter's debt servicing obligations. The article demonstrates this by tracing the production of these respective environmental and financial risks and, in particular, their co-determination. ${ }^{3}$ In the process, it makes two main contributions to the UPE literature. The first is conceptual and serves to formalize Swyngedouw's contention in the article's epigraph. The 'hybridized' water whose circulations we must examine in order to understand the socionatural 'cyborg' city is, today, increasingly financialized water (c.f. Bayliss, 2014); financial risk is inherent to its socialness. The second contribution is empirical. If, as the UPE literature (e.g. Swyngedouw and Heynen, 2003) suggests, today's 
cyborg city is highly uneven, its risks being borne in different measures by different constituencies, then financial mechanisms are implicated in the generation of this unevenness; indeed, in a place such as Washington D.C., it would be impossible to account for such unevenness without attending to financial processes and the ways in which they shape, and are shaped by, environmental processes.

The article is based upon the collation and analysis of written materials from a wide range of primary sources. These include, but are not limited to: government and government agency reports and policy briefs; documents prepared and made publicly available by DC Water, including audited financial reports, minutes of management meetings, environmental policy proposals and planning documents; public and interest-group responses to DC Water consultations; legal proceedings; court-adjudicated environmental policy agreements, and credit-rating agency decisions. These primary materials were supplemented with articles from the local and national press and scholarly sources.

The article contains three main sections. The first provides more contextual information concerning DC Water, the history and geography of CSO pollution in D.C. and the evolution of the DC Clean Rivers Project up until the point where its two-fold 'greening' began. The second section elucidates the key details of that greening. Finally, the third and longest section of the article assesses DC Water's greening project from the perspective of the key environmental and financial risks emanating from it, and their interrelation. This reading is organized around three core, connected themes that, I suggest, are crucial to understanding the political ecology of that project: time, space and money.

\section{Water and its CSO problem}

CSOs have long been a major environmental problem in the United States. The CSSs that generate these overflows are estimated to serve in the region of $40 \mathrm{~m}$ people in over 700 different communities across the country, and at the national level over a trillion gallons of CSOs - 'untreated wastewater, untreated industrial wastes and stormwater runoff' - cascade into receiving waterways annually (Ulrich, 2014: 4,7). Aquatic life is multiply impaired by the suspended solids, floatables (sanitary products and the like), oxygen-depleting substances and various other pollutants that the CSOs contain, while humans are directly affected by (knowingly or unknowingly) drinking, bathing in, or eating fish from CSO-polluted waters. Throughout its history, Washington, D.C. has been one of the worst affected regions of the country. CSOs, the District's Department of Energy and Environment reported in 2012, have 'major impacts on District Waters' (cited in NRDC, 2015: 2).

Prior to DC Water assuming responsibility for the capital's water and wastewater services in 1996, little had been done to address the local CSO issue. But during its first decade of existence, DC Water was moved to action by two connected sets of external developments.

The first of these was centred on the EPA, which had issued a formal CSO policy in 1989 and a revised version in 1994. The latter made it a requirement for all holders of National Pollutant Discharge Elimination System (NPDES) permits - essentially licenses to discharge pollutants, including in the form of CSOs, into receiving waters - to develop an LTCP. Compliance nationwide was initially limited, including in D.C., where work on developing an LTCP did not begin until 1998 (Ulrich, 2014:14), and took four years to complete. But codification of the EPA's Control Policy in the Clean Water Act (CWA) in 2000 lent the policy teeth. Thus emboldened, the EPA subsequently stepped up efforts to enforce compliance, with consent decrees representing an important tool to this end, and one that was used in D.C. as well as in numerous other jurisdictions. 
The second set of developments was more local. A medley of local environmental and recreational actors was perennially frustrated by what was perceived to be foot-dragging on the CSO issue at DC Water. By the late 1990s, patience had worn thin, and in 2000 these groups - including the Anacostia Watershed Society, Kingman Park Civic Association, American Canoe Association, Friends of the Earth and Sierra Club - filed suit against DC Water alleging violation of the CWA by failing to properly maintain CSO control facilities and failing to comply with water quality standards and effluent limitations. The EPA joined this suit in 2002. It was the force of this consolidated complaint that eventuated in the signing of the above-mentioned Consent Decree in 2005.

Critically, the Consent Decree tied DC Water to completing the Clean Rivers Project by 2025, at a total cost estimated at the time of \$2.4b (DC Water, 2005a: Appendix B). The Project was projected to reduce CSOs by $96 \%$ overall, and by $98 \%$ specifically on the Anacostia River. Equally significant were the particular types of infrastructure that DC Water committed to introducing in order to effect the clean-up process. As Ulrich (2014: 15) has subsequently noted, there was to be a modest guaranteed investment of $\$ 1.7 \mathrm{~m}$ in green infrastructure - also referred to as 'low impact developments' (LID) - such as rain barrels (to collect and store roof runoff), tree canopies (to intercept rainfall) and drainage trenches (to channel runoff away from impervious surfaces). But to all intents and purposes the Clean Rivers Project stipulated by the Consent Decree was, in infrastructural terms, a grey one. LIDs were marginal, essentially window dressing; $\$ 1.7 \mathrm{~m}$ was pocket money in the context of an overall Project cost of $\$ 2.4 \mathrm{~b}$. And the pivotal component of the grey infrastructural fix was to be the construction of a deep tunnel system engineered to capture and divert CSOs into underground sewer structures for their safe storage until such time as they could be conveyed to and treated at DC Water's Blue Plains wastewater treatment plant. Separate tunnel projects were planned for the Anacostia and Potomac Rivers and Rock Creek, with storage capacities of 'at least' $126 \mathrm{~m}, 58 \mathrm{~m}$ and $9.5 \mathrm{~m}$ gallons, respectively (DC Water, 2005a: 13-20).

By the time that DC Water embarked on its 'greening' of Clean Rivers around a decade later, much progress had been made. DC Water reported in 2015 that since 1996, untreated CSO volumes making their way into the Anacostia River had declined by $41 \%$ (from $2.14 \mathrm{~b}$ to $1.26 \mathrm{~b}$ gallons in an 'average' year), those affecting the Potomac had declined by $38 \%$ (from $1.06 \mathrm{~b}$ to $0.65 \mathrm{~b}$ gallons), while Rock Creek had seen a much smaller reduction (of $12 \%$, from $49 \mathrm{~m}$ to $43 \mathrm{~m}$ gallons). This added up to a $40 \%$ reduction on a system-wide basis. But, this had been achieved without any contribution from the planned tunnel network; rather, 'by replacing and upgrading pumping stations and control structures and separating combined sewers in selected sewersheds' (DC Water, 2015a: ES-4). Indeed, the tunnels for the Potomac River and Rock Creek had not even been started. And although work had begun on the tunnel system for the Anacostia River - nearly half of the length of the largest of the tunnels designed to divert CSOs plaguing the Anacostia, the 24,207 feet-long Blue Plains Tunnel, had been mined (DC Water, 2015b: 14) - DC Water was not expecting any further material reduction in levels of discharged pollutants until the first portion of the Anacostia system was operational, which it was (and still is) anticipating to occur in 2018.

Finally, if the complexion and constitution of local environmental risks had materially shifted, so also, and perhaps even more markedly, had those of financial risk. Though in 2015, DC Water was only midway through the agreed implementation period of the Clean Rivers Project (2005-2025), the cost had already been substantial, and had financially impacted various stakeholders. One was the federal government, from whom DC Water had actively sought financial assistance, and which by 2015 had provided $\$ 196 \mathrm{~m}$ in funds (DC Water, 2015a: K-14). Another, of course, was DC Water itself. Financial risk is most 
visible in its financial statements in the form of the outstanding long-term debt - bonds issued to finance capital investment programs such as Clean Rivers, and on which interest payments and principal repayment remain due - sitting on the liabilities side of its balance sheet. The value of this debt had mushroomed over the course of the decade in question. At 30 September 2004, DC Water had carried 'only' $\$ 785 \mathrm{~m}$ of long-term debt; exactly a decade later, the figure was $\$ 2.5 \mathrm{~b}$, and annual interest expenses had increased from $\$ 26 \mathrm{~m}$ to \$69m (DC Water, 2005b: 38,47; DC Water, 2015b: 36,40).

But as DC Water itself acknowledges, the cost of the Clean Rivers Project has been, and still is, 'borne mostly by District rate payers' (DC Water, 2015a: K-14). DC Water is an independent entity, thus as its recurring costs, including debt servicing costs, grow, it must in the long-term grow its revenues in order to remain a viable, solvent financial concern. And as Carol O'Cleireacain observed in a forensic 2012 analysis of the evolving cost implications of Clean Rivers, DC Water's revenues 'are primarily from fees and charges paid by retail and wholesale users' (O'Cleireacain, 2012: 4). These users have therefore been impacted accordingly, with the utility's approximately 670,000 retail customers - residential and nonresidential - bearing the primary brunt. Their growing financial contribution to the Clean Rivers Project has been experienced through two main channels. One is their water and sewer rates, which have increased significantly faster than inflation - at nine percent per annum, for example, between 2009 and 2012 (O'Cleireacain, 2012: 13). The other is the Impervious Area Charge (IAC) that DC Water introduced in 2009 specifically to help fund Clean Rivers. This is based on the impervious surface area of a customer's property, which DC Water calculates by using aerial photos. The charge increased from $\$ 1.24$ per month per 'equivalent residential unit' (ERU) (1000 square feet) in 2009 to \$11.85 in 2014. The combined upshot of rates and IAC increases was that the average monthly DC Water bill, based on one ERU and consumption of 6.69 centum (hundred) cubic feet per month, had risen from $\$ 33.65$ in 2004 to $\$ 74.05$ by 2014 (DC Water, 2015b: 90). This rate of increase, and the expectation that it would continue, led O'Cleireacain in 2012 firstly to urge DC Water to explore means other than ratepayer-backed debt financing to fund the remainder of the CSO clean-up project - which it has not done (Earthjustice, 2015: 7; NRDC, 2015) - and secondly to question whether customers could and would continue to tolerate the burden. 'What,' she asked (O'Cleireacain, 2012: 11), 'if rate payers' will or ability to pay fails?'

\section{The greening of Clean Rivers}

It was in this rapidly shifting context of increasingly entwined environmental and financial risks that DC Water initiated the two-fold 'greening' - of the clean-up infrastructure and of the debt financing used to fund its rollout - that concerns us in this article. We will look at the infrastructure side first.

The basic premise of using green infrastructure to reduce hazardous CSO discharges is straightforward. Where grey infrastructure solutions essentially take the level of stormwater runoff as given and focus on enabling treatment of CSOs before they reach surface waters, green solutions attempt to minimize the problem at source by restricting the amount of runoff entering the sewer system. 'Green infrastructure practices' explains the EPA (2014: 7) in a general statement regarding the possibilities for incorporating such practices into CSO control systems, "mimic natural hydrologic processes to reduce the quantity and/or rate of stormwater flows into the CSS. By controlling stormwater runoff through the processes of infiltration, evapotranspiration, and capture and use (rainwater harvesting), green infrastructure can help keep stormwater out of the CSS'. Importantly, introducing green 
infrastructure as a CSO control mechanism is unlikely to mean that grey infrastructure can be dispensed with altogether. Instead, it typically means that less grey infrastructure is required (EPA, 2014: 7).

At DC Water, plans to green the Clean Rivers Project began to be developed as early as 2009. Given that the 2005 Consent Decree locked in a grey trajectory, that trajectory could only be changed if the Decree itself was modified, and securing such a modification therefore became a strategic priority. To this end, DC Water entered into years of discussions with the EPA and with the District and federal governments (DeBonis, 2014; Ulrich, 2014: 16-18). As part of these discussions, it sought permission for a multi-year green infrastructure demonstration project at a cost of between $\$ 10 \mathrm{~m}$ and 30m (O'Cleireacain, 2012: 7). In December 2012, it received approval from the EPA and the Government of the District of Columbia to proceed with such a project in two pilot neighbourhoods (Ulrich, 2014: 17-18). Finally, in January 2014, DC Water published a formal proposal for modification of the 2005 Decree. The central proposed modification was to allow for large-scale, spatially extensive green infrastructure installations such as green roofs (designed to reduce stormwater runoff), rain gardens (which absorb runoff before it enters the sewer system) and permeable paving (which does the same), thereby converting DC Water's CSO solution from a grey to a hybrid green-grey one. This proposed infrastructural hybridization would not materially affect existing plans for the Anacostia River, where the original grey solution - the tunnel system in particular - was already far advanced. But plans for the Potomac River and Rock Creek would be radically altered. The tunnel planned for the former, at Georgetown waterfront, would be significantly scaled back (from a storage capacity of $58 \mathrm{~m}$ to $30 \mathrm{~m}$ gallons); and the tunnel planned for the latter, underneath Piney Branch (a Rock Creek tributary), would be jettisoned (although other, smaller, components of grey infrastructure would be retained). DC Water promised that the new green-grey solution would deliver equivalent CSO reduction to the grey solution, 'creating jobs and generating additional environmental benefits' (DeBonis, 2014) into the bargain.

DC Water's proposal attracted significant scrutiny. During the three-month public comment period, nearly 500 comments were received (DC Water, 2015a: ES-10). DC Water then made 'significant revisions to the draft plan in response to the comments' (DC Water, 2015a: ES-10). A crucial one (we will discuss others later in the article) was the particular nature of its green infrastructure commitment: initially expressed in dollar terms (\$60m for Rock Creek and \$30m for the Potomac), DC Water re-expressed its commitment in terms of managing the volume of runoff deemed necessary to deliver the agreed CSO reductions - viz., 'constructing sufficient green infrastructure and targeted sewer separation to manage the volume of runoff produced by 1.2" of rain falling on the number of impervious acres specified for the applicable sewershed' - in response to public concerns that 'a financial commitment would not ensure that the necessary amount of green infrastructure was constructed to provide the degree of CSO control required' (DC Water, 2015a: ES-10-11). In May 2015, a revised modification of the Consent Decree (EPA, 2015) was agreed with the EPA, the DOJ and the District of Columbia. This modification was approved and became effective in January 2016, with DC Water now 'enabled to invest at least $\$ 90$ million to build green infrastructure' (Hawkins, 2016; emphasis added).

Before turning to the parallel - and connected - greening of DC Water financing, one further layer of detail needs to be added to the green infrastructure side of the story. As the article will explore in greater depth below, the approved modification of the Consent Decree lacked certain important details concerning plans for green infrastructure implementation. As such, one condition of its acceptance was that DC Water would submit a more detailed 
green infrastructure 'program plan' for the EPA's approval within 12 months of the effective date of the amended Decree. In July 2016, it did (DC Water, 2016a). The program plan contains eight separate green infrastructure projects, of which five are in the Rock Creek sewershed and three in the Potomac. The first to be installed, in Rock Creek, incorporates rain gardens, permeable paving and downspout disconnection (separating roof downspouts from the sewer system and redirecting runoff onto pervious surfaces); it must be placed into operation, meaning that all control measures within the project are complete and functional, by the end of March, 2019. The first Potomac project must be operational three months later.

Meanwhile, as it was going through the drawn-out process of securing agreement to green the infrastructural foundations of its Clean Rivers Project, DC Water also set about greening the Project's financial foundations. Its first achievement in this regard was the issuance of a 'green bond' in 2014. As we saw earlier, DC Water had already raised substantial bond financing during the first, non-green, decade of the Project: between 2007 and 2013 inclusive, it issued bonds with a total combined face (par) value of $\$ 1.53 \mathrm{~b}$, and with maturities ranging from 25 to 35 years. Its inaugural green bond (Series 2014A) had a face value of $\$ 350 \mathrm{~m}$ and was one of three 2014 bond issues, worth $\$ 827.7 \mathrm{~m}$ in total and taking the total debt raised since the beginning of the Project to $\$ 2.36 \mathrm{~b} .^{4}$

A green bond is the same as a normal ('vanilla') bond in most regards. The key difference concerns the uses to which the funds provided by the bond are put. The funds must be used for specified 'green purposes' - say, a climate change mitigation project - and they cannot be used for anything else; they are, in this sense, ring-fenced. The buyer of a green bond therefore knows exactly how the money raised by the issuer through the bond's issuance is to be put to work. Some green bonds are 'unsecured' (backed only by the issuer's credit standing and good faith) while others are secured, either by the specific asset(s)/project(s) being financed or by the revenues of the issuing entity as a whole. DC Water's Series 2014A green bond was ring-fenced explicitly to finance the Clean Rivers Project - hence the green appellation. Since 2014, a further $\$ 225 \mathrm{~m}$ of new green bonds have followed, in three separate tranches in $2015(\$ 100 \mathrm{~m}), 2016(\$ 25 \mathrm{~m})$ and $2017(\$ 100 \mathrm{~m})$. All have been similarly ringfenced and all, notably, are secured by a pledge of DC Water's overall net revenues. Of the three, the 2016 tranche (Series 2016B, issued in September of that year) has received the most attention, and for good reason. Styled an EIB, it is a particular type of green bond, with three unique and vital characteristics setting it apart from DC Water's other green bonds.

First, the $\$ 25 \mathrm{~m}$ proceeds of the 30-year EIB are being used specifically to finance DC Water's first green infrastructure project - the above-mentioned Rock Creek installation. DC Water's other green bonds, by contrast, are being used to finance the grey components of the Clean Rivers Project. The EIB, then, occupies a somewhat privileged place in our analysis insofar as it is the knot that ties together the two processes we are especially concerned to unpack: the 'greening' of DC Water's infrastructural fix to its CSO problem on the one hand and, on the other, the greening of its debt financing.

Second, in a manner akin to so-called social impact bonds (Dowling, 2017), the amount of interest ultimately payable to the bond's holders will vary according to the environmental impact of the project that the bond's proceeds are being used to finance - in this case, the Rock Creek green infrastructure project. It is a 'Pay for Success' financing structure. Each year between 2016 and 2021, DC Water will pay interest of $\$ 857,500$ (the principal amount, $\$ 25 \mathrm{~m}$, multiplied by the interest rate on the bond, 3.43\%). But in 2021 (the "mandatory tender date'), something else may also happen. If the Rock Creek green infrastructure has outperformed expectations - which are for runoff reduction of between 18.6 and $41.3 \%$ then DC Water will make an additional payment to bondholders of $\$ 3.3 \mathrm{~m}$. If, however, 
the infrastructure underperforms, and runoff reduction is less than $18.6 \%$, the bondholders will be liable to pay DC Water the same amount. Meanwhile if, as expected, runoff reduction is between 18.6 and $41.3 \%$, no contingent payment will be made in either direction. The better the infrastructure performs, in other words, the more the financing raised by DC Water to build and operate that infrastructure will end up costing it. We will return in due course to the implications of this particular financing structure for the entangling of environmental and financial risk and for the distribution of the latter.

Third and finally, the EIB was issued in a different way to DC Water's other green bonds. Those other bonds were sold in public offerings; all and any investors could bid to purchase them upon issuance (i.e. in the primary market). Not so with the EIB, which was sold by way of private placement. A private placement is the direct sale of securities to a relatively small number of select investors. In the case of DC Water's EIB, there were two such investors. One was the Urban Investment Group of the investment bank Goldman Sachs, which bought the largest share of the bond $(\$ 23 \mathrm{~m})$. The other was the Calvert Foundation, a global 'impact investing' institution.

We now have in place, then, a foundational understanding of what the two-fold infrastructural and financial - 'greening' of the Clean Rivers Project has entailed. Both components have received widespread plaudits. Three of DC Water's green bonds have earned awards, and from both water and financial industry bodies (respectively, the International Water Association and the bible of the US municipal bond sector, The Bond Buyer). The environmental project finance lawyer Michael Curley described the contingent payment feature of the EIB as 'brilliant,' a 'stroke of genius' on the part of DC Water and its transaction coordinator, Quantified Ventures (Curley, 2017); the Environmental Defense Fund economist Diego Herrera also gushed, extrapolating from DC Water's seemingly successful transaction to speculate that 'EIBs could hold the key to the financing of wetland restoration projects to reduce flooding in coastal areas in the US and beyond' (Herrera, 2017). Some of the main reasons for such enthusiasm will be discussed below. Meanwhile, the CityLab staff writer Laura Bliss, while questioning whether all D.C. residents would reap the 'co-benefits' of DC Water's move to a hybrid green-grey infrastructure solution, had no doubt that such benefits - including 'improved air quality and health outcomes, more wildlife habitats, job creation' - were real enough (Bliss, 2015).

\section{Time, money and space in the co-constitution of environmental and financial risk}

\section{Time}

Arguably the most striking feature of the 2015 modified Consent Decree approved by the DOJ and the EPA is that the goalposts for CSO reduction by DC Water have been moved not so much sideways as backwards. In the original Decree, as we saw earlier, the entire Clean Rivers Project was to have been completed by 2025, with CSO discharges being reduced by $96 \%$ by that date. But that is no longer DC Water's duty. Instead, significant delays have been factored in and approved. At Rock Creek, DC Water has committed to completing the new hybrid green-grey infrastructure projects by 2030. In terms of the Potomac, infrastructure implementation will be completed by 2027 for the smaller CSO outfalls, and by 2030 - principally in the shape of the modified Potomac Tunnel - for the five largest CSO outfalls (DC Water, 2015a:ES-5-6). What this means, of course, is that the amendment of the Consent Decree has rubberstamped a significant extension of the time period during which levels of CSO pollution known to be severely damaging to the aquatic 
environment and to human health are permissible. And, it could have been worse. DC Water's January 2014 draft plan for modification of the Consent Decree had proposed a seven-year extension (i.e. to 2032) rather than a five-year one, but in the final modification DC Water made a two-year concession in response to hostile public comments.

On releasing the modified LTCP in 2015, DC Water moved to try to assuage concerns about this delay and the associated heightening of environmental risk. It did so by noting that even though completion would now be much later, the effects of the delay would be mitigated to some extent - an extent, notably, that it did not specify or attempt to quantify by the different temporal impact profiles of grey and green infrastructure solutions, respectively. Tunnels, upon being brought into use, provide abrupt and substantial step changes in CSO volumes, with no reduction occurring during construction; green infrastructures, by contrast, begin to reduce CSOs during their construction. 'While additional time is needed to effectively implement green infrastructure,' DC Water (2015a: ES-1) insisted, 'it will deliver earlier pollutant reductions through phased construction when compared to grey infrastructure'. And again: 'With the recommended plan, CSO reduction will begin to occur much earlier (in 2017)' (DC Water, 2015a: ES-6).

Does this argument hold weight? No - and not even in the best-case scenario, which is that the first green infrastructure projects for Rock Creek and the Potomac meet expectations and the remainder of the hybrid green-grey infrastructure program proceeds according to plan. (We will turn presently to what happens if the first projects do not succeed.) In this best-case scenario, the incorporation of green infrastructure may result in slightly lower cumulative CSO discharges by 2030 than the original grey-only solution would have at those Rock Creek and Potomac outfalls for which green infrastructure is now a significant or exclusive component of the infrastructural mix - though even DC Water's own comparative projections (DC Water, 2015a: ES-6) do not suggest this will necessarily be the case. But, crucially, the CSO volumes at these particular outfalls are much smaller in aggregate than the volumes at those outfalls (those numbered 020 through 024, on the Potomac River) where the infrastructural solution remains tunnel-based, and thus where reductions will, as per the original plan, occur on a discontinuous, step basis - only, now, delayed from 2025 to 2030. Across the former group of outfalls, the average annual aggregate CSO volume prior to Clean Rivers was $128 \mathrm{~m}$ gallons (of which $49 \mathrm{~m}$ at Rock Creek outfalls and $79 \mathrm{~m}$ at Potomac outfalls). Across the latter group, the average aggregate CSO volume was 560m gallons (EPA, 2015: 6-3). Even if the delay in completion of the infrastructure projects associated with the former group of outfalls does not prove environmentally damaging inasmuch as it is mitigated by the phased nature of green infrastructure construction, therefore, the delay of the tunnel project associated with the latter group substantially increases environmental risk because there is no such mitigation. There is simply a five-year delay, during which time enormous quantities of pollutants that would have been largely removed under the original plan will now continue to pour into the Potomac. Needless to say, DC Water neglected to provide comparative CSO annual reduction projections for these particular outfalls under the two scenarios (i.e. the original versus modified Consent Decrees). In any event, the net effect of the approved modification, across all Potomac and Rock Creek outfalls, over the 2017-2030 period will be vastly greater volumes - running into the hundreds of millions of excess gallons - of untreated effluent.

And this, as intimated, is the best-case scenario, under which the first two green infrastructure projects - each of which is to be operational by sometime in 2019 - fulfil expectations and thus the rest of the modified Clean Rivers Project can proceed according to the fine-tuned 2016 plan (DC Water, 2016a). But what if, for whatever reason, they do not? 
DC Water has contingency plans in place, agreed with the EPA. Once bedded in, the initial Rock Creek and Potomac green infrastructure projects will be evaluated, most likely during 2020 or 2021. And:

If, based on that evaluation, it is determined that it is impractical to complete all the specified green infrastructure projects by the specified deadlines, then DC Water would be required to construct the grey controls as specified in the LTCP Modification. Should this occur, DC Water would be required to construct the grey controls within the same timeframe allowed for green infrastructure so there is no extension of the time allowed for implementation. (DC Water, 2015a: ES-11)

In other words, if the results of the first two green infrastructure projects suggest that the wider hybrid green-grey project plan is in fact 'impractical,' DC Water will simply revert, in effect, to the original grey-only infrastructure approach, the only material difference besides a smaller Potomac Tunnel (40m versus the original $58 \mathrm{~m}$ gallon-capacity) now being that completion will be in 2030 rather than 2025 - and of course with no 'phased construction' providing mitigating $\mathrm{CSO}$ reduction effects in the meantime.

In short, through the delays it entails, DC Water's shift to a hybrid green-grey CSO solution has markedly amplified local environmental risk for the period through to 2030 . (As noted, long-term, post-project-completion CSO reduction is anticipated to be equivalent under the original and modified plans). If the green-grey plan is fully implemented, accumulated CSO pollution to 2030 will be greater than under the original grey-only solution; if the plan ultimately needs to be aborted in favour of reversion to a (delayed) grey-only solution, accumulated pollution will likely be greater still. Denying this amplified environmental risk, DC Water denies, too, that there are related financial risk implications: it has maintained throughout that the costs of the original and revised clean-up plans would be 'approximately equivalent' (DC Water, 2015a: K-17). But environmental risks, to return to our expanded UPE framing, bleed indelibly into financial ones. Time is not just pollution; it is also, and partly for this reason, money.

In particular, the risk of the green-grey plan ultimately proving 'impractical' is clearly financial as well as environmental. As critics of DC Water's revised plans pointed out, the criteria identified by the modified Consent Decree for assessing overall plan practicability subsequent to evaluation of the first two green infrastructure projects 'constructability, operability, efficacy, public acceptability and cost per impervious acre treated' (EPA, 2015: Appendix F, pp.3, 5) - are in most cases exceptionally fuzzy and subjective, none of them being defined (e.g. NRDC, 2015: 8; RCC, 2015: 2). Nor is it clear, as the influential environmental advocacy group NRDC (2015: 8) observed, what standards will apply to the EPA's decision to approve or disapprove DC Water's practicability analysis. The whole business is, in sum, fundamentally uncertain. Unsurprisingly, many of the critics, the NRDC among them, thought it would make more sense to have a series of checkpoints along the way rather than a single, all-ornothing cut-off point; after all, it is hardly inconceivable that if DC Water were to assess the first two projects positively and then fully commit to the green infrastructure approach, it might, thereafter, still 'encounter unforeseen practical hurdles and may need to adapt its plans accordingly' (NRDC, 2015: 8; cf. Earthjustice, 2015:4). Indeed, the only thing that does seem certain is the one thing that DC Water has continued, explicitly and implicitly, to deny - that 'if the first green infrastructure project does not work out as anticipated, the schedule will slip' (RCC, 2015: 2), and costs will mount. We will consider the nature of those costs in the next section, where money is our main focus. 


\section{Money}

DC Water's turn toward greater 'green' financing of the Clean Rivers Project has, as we saw, been widely lauded - no more so than in the case of the EIB. But as we also saw, aside from the specific case of the EIB, there are in reality few significant differences between green bonds and normal bonds. The only categorical difference is that the proceeds of green bond issues must be used for the particular purposes specified by the bond issuer when selling the bond. In DC Water's case, its green bonds must be used to finance Clean Rivers; it has said they will be. Yet there was nothing to stop DC Water from using the plain vanilla bonds it issued between 2007 and 2013 also to finance Clean Rivers - indeed much of the funding raised through those issues was used precisely in that way - and nor was there anything to stop it thereafter from continuing to finance Clean Rivers with normal bonds. The key question to ask about DC Water's green financing, then, is one that most commentators, smitten by its apparent novelty, have tended to ignore. Has it actually been good for DC Water and thus, ultimately, for its ratepayers? Has it decreased or increased financial risk?

Let us consider DC Water's 'normal' green bonds, in other words those besides the EIB, first. How much have they cost it? And more importantly, how does the cost of its green bonds compare with the cost of its non-green bonds? On two occasions, in 2015 and then in 2017, DC Water has issued green bonds alongside vanilla bonds, allowing us directly to compare capital costs in each case. In 2015, the costs of green and vanilla were equivalent. 'Although no current proven price differential for Green Bonds,' the finance team reported of the Series 2015A/B bond sale, 'hope is that with [sic] market growth in green bonds will build investor base that does offer a price differential' (DC Water, 2015c: 42). But it did not happen, or at least the differential that emerged was not the one anticipated. Fast forward to 2017 and the simultaneous issue of 2017A (green) and 2017B (vanilla) bonds. The former cost DC Water a total yield of $4.14 \%$; the latter, a total yield of $3.63 \% .^{5}$ The green bonds were dearer. To a degree, this differential was explained by their longer maturity: the average maturity of the 2017A bonds was 32 years, to 2017B's 18 (DC Water, 2017b: 39), and bond yield usually increases with maturity since investors demand a higher return for keeping their capital tied up for a longer period (Christophers, 2017: 71). But the longer maturity does not fully account for the differential in this case. At the time of the sale (31 January 2017), the yield curve for municipal bonds at maturities above 15 years was notably flat. At most, the market was demanding 30 extra basis points $(0.3 \%)$ of yield for municipal debt with a maturity of 32 versus 18 years. ${ }^{6}$ It definitely was not demanding the 50 extra basis points it managed to extract from DC Water. Investors were, if anything, charging DC Water - and in turn, its retail customers - more for issuing green than vanilla debt; they were certainly not charging it less.

What, then, of the vaunted EIB? What have been its specific risk implications? Before turning to its interest costs, let us consider more generally its role in (re)constituting and (re)distributing risk. This is a necessary task because much of the enthusiasm for the instrument rests on its perceived effectiveness, from DC Water's perspective, in these particular regards. The joint press release issued on the day of the bond's placement, for instance, crowed that by virtue of the bond 'the performance risk of the green infrastructure in managing stormwater runoff is shared amongst DC Water and the investors', with DC Water's chairman 'congratulat[ing] the financing team for creatively reducing project risk' (DC Water, 2016b); the EIB fact sheet says that the bond 'allows DC Water to better manage or hedge a portion of the risk associated with the green infrastructure' (Goldman Sachs, 2016: 3); Alisa Valderrama, senior policy analyst at the NRDC, wrote of the EIB both reducing financial risk and mitigating performance risk (Valderrama, 2016), and so on. 
Hedging, managing, mitigating, reducing and sharing financial, infrastructural, performance and project risks - these are strong, likely impactful, claims. But what to make of them?

An analysis of the EIB by the EPA's Water Infrastructure and Resiliency Finance Center is especially helpful in this respect (EPA, 2017). It considers carefully the various types of risks involved in the Rock Creek green infrastructure project and its funding through the EIB. Six types of risk are identified (EPA, 2017: 4): performance of the green infrastructure, market/financing risk, counterparty risk, construction risk, operation and maintenance $(\mathrm{O} \& \mathrm{M})$ and capex/lifecycle risk, and regulatory risk. In two of the six cases, the analysts claim, the risk resides with DC Water's investors, namely Goldman and Calvert. One is performance of the green infrastructure; we will consider this risk momentarily. The other is counterparty risk: what the EPA is saying here, effectively, is that while DC Water can be certain of receiving the contingent payment from Goldman and Calvert if the infrastructure underperforms CSO reduction expectations, Goldman/Calvert cannot be equally certain of payment if the infrastructure outperforms, because the EIB is subordinate to DC Water's other bonds and thus the contingent payment would be payable only after all principal and interest payments due on those other bonds had been paid, which DC Water's net revenues might not allow. All of the other four types of risk, meanwhile, remain wholly with DC Water, including market/financing risk. DC Water retains responsibility for construction (it has to pay interest and repay principal whether the project is completed or not); DC Water is responsible for any changes in laws, regulations or policy; DC Water is responsible for O\&M for the life of the EIB transaction; and, because the interest rate on the bond is reset at the mandatory tender date in 2021, 'DC Water retains the financing risk'. In sum, the EIB clearly does not comprehensively transfer risks away from DC Water and its ratepayers in the way widely suggested.

The EPA is, nonetheless, positive - from DC Water's perspective - about the EIB in relation specifically to the performance risk of the Rock Creek green infrastructure. 'DC Water', it says, 'has effectively hedged performance risk'. It goes on to say that the contingent payment DC Water would receive in the event of infrastructure underperformance would provide it with 'additional resources to address performance deficiencies' (EPA, 2017: 4). If the Rock Creek green infrastructure does not work as expected, the EPA is saying, the contingent payment would compensate for this; the risk has been successfully hedged.

But has it? It would be hard to answer in the affirmative. Even the key institutional protagonists of the transaction (excluding Goldman) - Beth Bafford at Calvert, Eric Letsinger at Quantified Ventures, and DC Water's Chief Financial Officer, Mark Kim admit that the contingent payment receivable on grounds of green infrastructure underperformance at Rock Creek would only 'partially [offset] the expense of testing this solution' (Bafford et al., 2017: 230). And even if the contingent payment did fully offset the testing expense, it would hardly offset the wider and ultimately wasted expense, of time and energy as well as money, incurred in taking DC Water down the green infrastructure route only to have to reverse course at the eleventh hour and revert to the original grey infrastructure solution. For that, as we have seen, is precisely what DC Water will have to do if its first green infrastructure projects do not meet expectations. What will that wider, wasted expense amount to? Well, there is the accrued historic expense - more than a decade of time and energy, given that it will be 2021 before it is known how well the green infrastructure pilot has performed and thus whether a contingent payment need be made and whether the wider hybrid infrastructural solution can be rolled out as planned; tens of millions of dollars, with DC Water already by mid-2015 having 'invested \$14 million in ratepayer funds to further our understanding of this innovative [green infrastructure] 
solution to stormwater control' (DC Water, 2015a: n.p.) before even breaking physical ground on the project; and who knows how much political capital at local and national scales. And then, of course, there is the future expense - the cost, that is, of turning the metaphorical oil tanker around and, in 2021 or 2022, reverting to the currently shelved grey infrastructural solution and scrambling to complete it by 2030. If, in short, DC Water in 2021 has to abandon the green infrastructure experiment and start again, $\$ 3.3 \mathrm{~m}$ from Goldman and Calvert will represent scant consolation, especially to the D.C. ratepayers who will have paid - and would then continue to pay - for the costs of failure. Bafford et al. (2017: 230) happily exclaim that with the EIB structure, 'all parties' interests are wellaligned,' but it is notable that their 'all parties' category comprises just the investors and DC Water; it is far from clear that ratepayers' interests - financial or, as we have seen, environmental - are equally 'well aligned'. The EIB does not in reality provide anything like the performance-risk mitigation potential widely imputed to it. Still less does it, as Liz Farmer (2016) claimed, 'insure against failure'. At best, the contingent payment due to DC Water would provide a mild tonic, a scrap to be thrown to the angry hordes, in the event that the green infrastructure solution fails.

The EIB, furthermore, is, in and of itself, strikingly expensive for DC Water as a form of financing. Private placements very often are: there is no competition among potential buyers to push prices up (and thus financing costs down), and rates 20-100 basis points higher than those paid in public offerings of comparable instruments are frequently required to entice investors. The EIB fits this pattern, but in extremis. Looking at the first five years of the transaction through to the mandatory tender date (at which point the deal refinances on terms currently unknowable), the EPA's Water Infrastructure and Resiliency Finance Center compared the interest rate that DC Water is paying Goldman and Calvert with the prevailing market rate on similarly rated five-year municipal bonds. If the green infrastructure performs to expectations (and there is no contingent payment in either direction), DC Water's interest cost is of course $3.43 \%$, the bond's coupon; in the underperform scenario, where the investors pay DC Water $\$ 3.3 \mathrm{~m}$, the effective interest cost would be $0.81 \%$; and in the over-perform scenario, where the $\$ 3.3 \mathrm{~m}$ is paid by DC Water, the effective cost would be $5.801 \%$. And the prevailing market rate? Just $0.98 \%$ (EPA, 2017: 3). In other words, if the green infrastructure performs to or exceeds expectations, DC Water is paying far above market rates. Even the $3.43 \%$ base-case cost is, as one critic of the deal, Dan Kaplan of King County, Washington's Wastewater Treatment Division, said, 'exceptionally high' (quoted in Farmer, 2016); and the less said about the $5.801 \%$ rate the better. The comparison with prevailing market rates throws a different light, too, on the underperformance - i.e. green infrastructure failure - scenario and its risk allocation. As we have seen, DC Water argues that the $\$ 3.3 \mathrm{~m}$ payment from the bondholders would be a form of positive compensation, a one-off financial upside to mitigate the downside of infrastructural failure and attendant costs. But EPA's analysis shows it is in fact nothing of the sort. $0.81 \%$ - the effective interest cost of the EIB to DC Water if the green infrastructure underperforms and the contingent payment is received - is more or less the rate $(0.98 \%)$ that the market in general was offering for 'normal' five-year municipal bonds. In other words, $0.81 \%$ (or $0.98 \%$ ) should arguably have been DC Water's base rate (payable in the 'meets expectations' scenario), not the rate paid in the event of failure. The 'failure premium' nominally provided by the EIB structure is, in reality, a mirage.

The most contradictory aspect of the EIB and its costly amplification of financial risk, lastly, is this: green infrastructure is a proven technology for CSO reduction. So why hedge (imperfectly) in the first place? As Farmer (2016), paraphrasing Kaplan, says, 'rain gardens 
and permeable surfaces aren't new, untested technology'. Far from it. Their success is well documented. In the words of the NRDC (2015: 3):

Green infrastructure is a proven strategy that is being deployed at a large scale in cities across the country. Over three decades of research and implementation of green infrastructure technologies establish that, when properly implemented and maintained, they achieve quantifiable runoff reductions that can predictably reduce or prevent overflows. Scientific studies and literature reviews provide ample information regarding the typical runoff volume reductions achieved by specific green infrastructure practices, providing a high degree of confidence about their expected performance.

Indeed, the performance thresholds that DC Water agreed with Goldman and Calvert in structuring the EIB - for runoff reductions of 18.6 and $41.3 \%$ - have a $95 \%$ confidence interval (DC Water, 2016c: 44). That is to say, DC Water believes there is a $95 \%$ chance of fully implemented green infrastructure at Rock Creek achieving runoff reduction of between 18.6 and $41.3 \%$; the probability of over or underperformance is deemed equal at $2.5 \%$ in each case (Goldman Sachs, 2016: 4). It is easy therefore to sympathize with the viewpoint of Kaplan, who, reported Farmer (2016), 'doesn't see the point in DC Water hedging its bets that the projects won't do their jobs. "If there's some new technology that needs to be tested and there simply aren't the resources within the utility to commit the personnel and technology to do it," he said, "then perhaps [this financing mechanism] could be a tool.", But green infrastructure is not such a technology. It works.

\section{Space}

One way to think about the apparent contradiction of DC Water hedging against the failure of a technology with proven success is to consider the EIB as a hedge not - or not only against green infrastructure's underperformance, but against the utility's own. Amid all the hullabaloo surrounding the EIB when it was issued in 2016, everybody missed what was, perhaps, the key statement from the counterparties to the transaction: 'By structuring a contingent payment based upon the effectiveness of green infrastructure, DC Water is focusing on outcomes (reducing stormwater runoff) in addition to outputs (whether the required number of impervious acres of green infrastructure is built)' (Goldman Sachs, 2016: 3). Why is this such an important statement? Because it recognizes that in order for green infrastructure to do the job of reducing stormwater runoff, it has to be built in the first place; and, in acknowledging that there is an element of uncertainty around this eventuality ('whether the required number of impervious acres of green infrastructure is built'), the statement discloses an additional, heretofore unmentioned, vector of 'performance' risk. Namely, alongside the risk (seemingly small) of green infrastructure not working, there is the risk (perhaps not so small) of DC Water not being able to successfully install it.

In this final part of the article, we focus more closely on this particular risk, and on its potential implications. The aforementioned statement, I suggest, is indicative of much wider uncertainties surrounding DC Water's plans for green infrastructure implementation and the likely costs thereof. In 'greening' the Clean Rivers infrastructural solution, DC Water has in fact taken the District and its residents from a position of relative certainty - about infrastructural works and their feasibility and costs - to one of radical uncertainty.

One significant area of uncertainty, for example, concerns the utility's plans for maintaining its various green infrastructure projects in the long term, in the happy event that the first two such projects prove successful and thus the remainder of the wider green infrastructure network can be rolled out as hoped. The environmental law organization 
Earthjustice sharply criticized DC Water and the EPA for not formally memorializing specific commitments to green infrastructure maintenance in the modified Consent Decree. Its criticism contained the crucial recognition, moreover, that this oversight and the uncertainty it breeds does not only constitute a financial risk. It is also, by extension (or determination), an environmental one. For if later there arise 'unanticipated contingencies' or 'budgetary constraints and interagency disputes among District agencies regarding the responsibility for funding maintenance', the lack of formal, binding provisions in the Decree could lead to 'maintenance of green infrastructure not being assured' or 'delays or even complete failure to maintain green infrastructure installations' (Earthjustice, 2015: 14-15).

In terms specifically of DC Water's ability to actually install green infrastructure at the necessary scale, the greatest uncertainty concerns space. In the dense, urban environment of Washington, D.C., does DC Water actually have access - or the certainty of acquiring access, and at an affordable price - to the land needed to assemble the spatially extensive green infrastructure surface installations it is planning? The NRDC was, one might have thought, stating the obvious when it wrote:

Installing small-scale green infrastructure practices on dozens of acres across an urban area poses practical difficulties that, while not insurmountable, must be anticipated and addressed in advance. Most critically, the plan must ensure the availability of sufficient land for the planned practices in the sewershed areas and guarantee implementation of those practices, especially when they are installed on privately-owned land (NRDC, 2015:6).

Presumably DC Water had recognized these requirements in developing its green infrastructure proposals, and had planned accordingly? The evidence suggests not. Not only was the modified Consent Decree vague about where exactly green infrastructure would be installed and whether the necessary land was available - Earthjustice (2015: 13) noting that 'DC Water does not appear to have conducted a detailed assessment of whether adequate publicly-owned land in the relevant sewersheds is available for DC Water to meet its requirements to control specified acreage in each sewershed with green infrastructure, or whether sufficient privately-owned land is available to make up for any shortfall in public land'. The Decree was, in this regard, also riddled with inconsistencies: 'certain sections of the proposal state that public land is sufficiently available for full implementation, while others suggest that some implementation must be accomplished on private land. These inconsistencies are cause for concern and indicate that DC Water does not actually know whether adequate opportunities for green infrastructure practices exist on publicly-owned land' (NRDC, 2015: 6). All of this explains the NRDC's conclusion that while it was reasonably certain that green infrastructure practices would achieve the promised CSO reductions if fully implemented, there was much 'less certainty that the practices can in fact be fully implemented given the practical constraints posed by the urban setting of the relevant sewersheds' (NRD, 2015: 5; original emphasis).

The subsequent green infrastructure 'program plan' released in 2016 (DC Water, 2016a) did not provide any great comfort that those land availability issues had or have been satisfactorily resolved. In attempting to determine where in the relevant sewersheds green infrastructure could be most effectively implemented, DC Water had undertaken an extensive analysis of properties in three main ownership categories - publicly owned property within the right-of-way (ROW), other publicly owned properties (public schools, recreation centres, etc.) and private property. Furthermore, using detailed geographical information system data, this analysis sought to estimate the space available within each sewershed for green infrastructure projects by factoring in not only land ownership but land use (commercial, residential or institutional), development density and land cover (e.g. roads 
and alleys, buildings and sidewalks). Yet the one thing it did not specifically factor in was, arguably, the most important thing of all - whether the land in question, including public land, was actually available to it to use.

Having done this evaluative work, in any event, DC Water concluded in its program plan that public land would indeed not be sufficient in and of itself for the full scale of green infrastructure provision being envisaged - 'the majority', but not all, 'of green infrastructure will be implemented in the ROW' (DC Water, 2016a: 3-8). However, a sizeable questionmark was left hanging over how much green infrastructure DC Water can reasonably expect to implement on private land. For private property installations, it appears to be relying largely on 'incentivizing' green infrastructure, particularly in the form of a downspout disconnection incentive program incorporating rain barrels (DC Water, 2016a: 2-10, 2-14). But incentivization means uncertainty, as well, typically, as expense; nobody knows exactly how private property owners will respond. Indeed, DC Water's own review of existing incentive-based downspout-disconnection initiatives in the District, which offer financial incentives including fee discounts based on the volume of stormwater retained, found that success had been limited. A pilot led by the local nonprofit group Rock Creek Conservancy was particularly disappointing, hampered by 'the significant level of effort required to persuade property owners to disconnect, and the higher than anticipated personnel costs'. This pilot was superseded by a program offering, necessarily, 'a wider range of green infrastructure incentives to property owners' (DC Water, 2016a: 2-15).

And even in terms of public-land installations, radical uncertainty remains. D.C. public land is not necessarily DC Water's land. 'The majority of DC Clean Rivers Project green infrastructure projects,' the 2016 program plan acknowledged, 'will be located on land that DC Clean Rivers Project does not own' (DC Water, 2016a: 2-11). Such land, obviously, is not simply DC Water's to do with what it will. Whether sufficient quantities of public land will be made available to DC Water to install the majority portion of the green infrastructure network it expects to install on it is anybody's guess. DC Water itself has - or at least, in 2016, had - no guarantees. Hence, firstly, its acknowledgement that for it to have any chance of realizing its green infrastructure ambitions, it would need to 'work closely with appropriate agencies such as the District Department of Transportation and the Department of Energy and Environment in the District' (DC Water, 2016a: 2-11). Hence also, secondly, its acknowledgment that before ground could be broken on new green infrastructure projects, either DC Water or its contracted design builders would need to obtain construction rights from 'the Department of General Services, National Capitol Planning Commission, U.S. Commission of Fine Arts/Old Georgetown Board, State Historic Preservation Office, and the Washington Metropolitan Transit Authority, as applicable' (DC Water, 2016a: 4-19). And hence thirdly, and most tellingly of all, its admission that apart from the pilot green infrastructure projects in each of the two sewersheds, the project location delineations provided in the program plans were (just as they had been in the modified Consent Decree) only 'approximate' (DC Water, 2016a: 4-2, 4-11). How, given the degree of uncertainty still remaining in regard to land availability, could they be anything but? Even in the case of the two pilot projects, in fact, it transpired that location was still not yet set in stone. DC Water promised that the locational boundaries of these installations were merely 'unlikely to change substantially'.

The reality is that the project of transitioning Clean Rivers from grey to green-grey infrastructure has been shot through with uncertainty from the very start. George S Hawkins, who became General Manager of DC Water in 2009 and whose zeal has driven this transition, provided unwitting testimony of this uncertainty as early as 2011 . Among the reasons to transition to green-grey infrastructure, he said, were that 'the environmental 
outcomes might be better' and, 'conceivably, to save our ratepayers some money' (cited in DeBonis, 2011). The transition, in other words, would seed environmental risk (outcomes 'might' be better); and it would seed financial risk (ratepayers could 'conceivably' save money). So it has proved. Risk - environmental, financial, and the two entangled saturates the transformed socioecological milieu that DC Water has constituted through its 'greening' of the Clean Rivers Project, and land availability issues are at the very root of it.

\section{Conclusion}

The next few years are likely to be turbulent ones in the worlds of DC Water, its hundreds of thousands of customers in Washington D.C., and the CSOs that continue to blight local waterways. DC Water has over the course of recent years abandoned a solution to its CSO problem that offered relative certainty and replaced it with a solution characterized by myriad interlocking uncertainties. Will DC Water manage to install green infrastructures on schedule and on the scale required? Exactly how well will these green infrastructures perform? Will DC Water's customers continue to be able to pay the spiraling prices charged them? And will DC Water itself continue to be able to pay the spiraling costs - especially debt servicing costs - that explain those price rises?

Various interested parties will be watching closely. DC Water's customers, of course, will be among them, concerned not just about their monthly bills but the health of their local waterways. So too will investors in DC Water's debt. And then, of course, there is the EPA. The EPA's support has been essential to DC Water's change of tack on infrastructure; without it, DC Water would have had to see through the commitment to a grey infrastructure solution embedded in the original 2005 Consent Decree. If DC Water has exposed itself to considerable reputational (as well as financial) risk in adopting a strategy attended by so many uncertainties, it is clear that the EPA, in rubberstamping that strategy, has too.

The main aim of the article has been to demonstrate that the DC Water case represents an instructive one for the field of UPE, concerned as it is to understand the interaction of environmental and social processes in the formation of urban landscapes, but overlooking, to date, the financial aspects of the social. As I observed at the outset, this oversight becomes increasingly hard to justify as cities become increasingly financialized. Following and extending Swyngedouw's (1996) argument that the waters flowing through our cities are socionatural hybrids, I have suggested that the 'greening' of DC Water's Clean Rivers Project has produced a constellation of risk that defies easy disaggregation into 'environmental' and 'financial' components. Environmental and financial risk are here codetermined to the extent that one comes to inhabit the other. The risk that today pollutes the Potomac and Anacostia Rivers and Rock Creek is financial no less than it is environmental, even if its financialness is less readily detectable.

Since the two-fold greening of Clean Rivers is ongoing, it is of course too early to judge its success (however one may care to evaluate the latter, and from whoever's perspective). But what this article has shown is that whatever 'success' is ultimately achieved, it will have come at the cost of considerable environmental-financial risk augmentation that is belied - if not denied - by the 'green' monikers. Those risks are very much live ones, and there is, the article has shown, nothing 'natural' or inevitable about them. If a key theoretical contribution of the article, then, has been to conjoin environmental and financial risks, a key empirical contribution has been to show that just as - with apologies to Gordon Gekko - greed is not good, neither, necessarily, where environmental and financial risks and their conjoining is concerned, is 'green.' 


\section{Acknowledgements}

I am grateful to Patrick Bigger, Emily Rosenman, three anonymous referees and the editor, Leila Harris for reading and commenting constructively on earlier drafts. The usual disclaimers apply.

\section{Declaration of conflicting interests}

The author(s) declared no potential conflicts of interest with respect to the research, authorship and/or publication of this article.

\section{Funding}

The author(s) disclosed receipt of the following financial support for the research, authorship and/or publication of this article: I am grateful to the Swedish Research Council (Vetenskapsrådet) for funding the research reported in this article, through grant number 2015-01694.

\section{Notes}

1. The lack of substantive attention to financial processes in the most influential UPE anthology (Heynen et al., 2006) and in recent overviews of the field - such as Nik Heynen's three progress reports in Progress in Human Geography (2014, 2016 and 2017) - is symptomatic of a broader dearth in the literature.

2. In this article, I use the terminology of 'green' and 'grey' uncritically; it is the terminology used by all the relevant actors in the case. It is worth noting, however, that these discursive conventions are not innocent: they underpin different visions of sustainable urbanity and perform different ideological works (Wachsmuth and Angelo, 2018).

3. What the article does not consider are DC Water's rationales for undertaking the two-fold greening of infrastructure and financing (for details of which see, respectively, DC Water, 2015a: ES-6-ES-8; DC Water, 2017a: 2-3). This is not because they are unimportant. Neither is it because these justifications are necessarily misplaced or unfounded. Rather, they fall outside of the article's remit of exploring the relationship between environmental and financial risks in the shaping of urban socioecological landscapes. The decisions seeding the amplified risks to which the article points may have been entirely justifiable - but the question of whether they were is not this article's concern.

4. 'Current DC Water Outstanding Debt'. www.dcwater.com/sites/default/files/finance/rates/Rating Current\%20Debt_FY2017_6.29.2017_1.pdf (last accessed 15 August 2017).

5. Note that these percentages are not the actual interest costs (coupons). Rather, they represent 'total interest cost', which is the effective interest cost (or yield) once the premium or discount to par value paid by the bond buyer at issuance is factored in.

6. See www.vmbb.org/wp-content/uploads/January-31-2017-AAA-Municipal-Bond-Data.pdf (last accessed 17 August 2017).

\section{References}

Bafford B, Kim M and Letsinger E (2017) Investing in innovation and outcomes: The story of DC water's environmental impact bond. In: Bartlett B, Bugg-Levine A, Erickson D, et al. (eds) What Matters: Investing in Results to Build Strong, Vibrant Communities. San Francisco: Federal Reserve Bank of San Francisco, pp. 228-232.

Bayliss K (2014) The financialization of water. Review of Radical Political Economics 46: 292-307.

Bliss L (2015) D.C.'s polluted rivers are getting a green makeover. Available at: www.citylab.com/ design/2015/06/dcs-polluted-rivers-are-getting-a-green-makeover/394745/ (accessed 6 April 2018).

Buerger M (2012) The Potomac River, in good health and bad. The Washington Post, 2 May.

Christophers B (2017) The performativity of the yield curve. Journal of Cultural Economy 10: 63-80. 
Curley M (2017) Green impact investment: The real thing. Available at: www.huffingtonpost.com/ michael-curley/green-impact-investment-t_b_14546626.html (accessed 6 April 2018).

Cutter S and Emrich C (2006) Moral hazard, social catastrophe: The changing face of vulnerability along the hurricane coasts. The Annals of the American Academy of Political and Social Science 604: $102-112$.

DC Water (2002) Combined sewer system long term control plan: Final report. Available at: www. dcwater.com/sites/default/files/Complete\%20LTCP\%20For\%20CD.pdf (accessed 6 April 2018).

DC Water (2005a) Consolidated civil action no. 1:00CV00183TFH. Consent Decree. Available at: www.dcwater.com/sites/default/files/ltcp_consent_decree.pdf (accessed 6 April 2018).

DC Water (2005b) Comprehensive annual financial report 2004. Available at: www.dcwater.com/sites/ default/files/documents/2004\%20CAFR.pdf (accessed 6 April 2018).

DC Water (2015a) Long term control plan modification for green infrastructure. Available at: www. dcwater.com/sites/default/files/green-infrastructure-ltcp-modificaitons.pdf (accessed 6 April 2018).

DC Water (2015b) Comprehensive annual financial report: Fiscal year ended September 30, 2014. Available at: www.dewater.com/sites/default/files/2014\%20CAFR.pdf (accessed 6 April 2018).

DC Water (2015c) Finance and Budget Committee, Thursday, October 22, 2015. Available at: https:// dcwater.com/sites/default/files/October $\% 2022 \% 2 \mathrm{C} \% 202015 \% 20$ Finance $\% 20$ and $\% 20$ Budget $\%$ 20Committee\%20Meeting\%20Agenda.pdf (accessed 6 April 2018).

DC Water (2016a) Green infrastructure program plan. Available at: www.dcwater.com/sites/default/ files/program_plan_final_with_appendix_2016_0729.pdf (accessed 6 April 2018).

DC Water (2016b) DC Water, Goldman Sachs and Calvert Foundation pioneer environmental impact bond. Available at: www.dcwater.com/whats-going-on/news/dc-water-goldman-sachs-and-calvertfoundation-pioneer-environmental-impact-bond (accessed 6 April 2018).

DC Water (2016c) Finance and Budget Committee, Thursday, June 23, 2016. Available at: www. dcwater.com/sites/default/files/6-23-2016.pdf (accessed 6 April 2018).

DC Water (2017a) DC Water's Green Bond Report: Fiscal Year 2016. Available at: www.dcwater. com/sites/default/files/FY\%202016\%20Green\%20Bond.pdf (accessed 6 April 2018).

DC Water (2017b) Finance and Budget Committee, Thursday, February 23, 2017. Available at: www. dcwater.com/sites/default/files/Finance\%20and\%20Budget\%202-23-2017.pdf (accessed 6 April 2018).

DeBonis M (2011) D.C. Water's tunnel vision, with green in mind. The Washington Post, 19 May.

DeBonis M (2014) 'Green' modifications proposed to D.C. clean-water plan; environmentalists are skeptical. The Washington Post, 23 January.

Dowling E (2017) In the wake of austerity: Social impact bonds and the financialisation of the welfare state in Britain. New Political Economy 22: 294-310.

Earthjustice (2015) Comments of Jennifer C. Chavez, Earthjustice. Available at: www.dcen.net/dc/wpcontent/uploads/2015/07/Earthjustice-et-al-Comments-on-Lodged-Decree-Modification_07-252015.pdf (accessed 6 April 2018).

EPA (2005) Civil Action No. 1:00CV00183TFH. Consent Decree. Available at: www.epa.gov/sites/ production/files/documents/dcwasa-cd.pdf (accessed 6 April 2018).

EPA (2014) Greening CSO plans. Available at: www.epa.gov/sites/production/files/2015-10/ documents/greening_cso_plans_0.pdf (accessed 6 April 2018).

EPA (2015) Consolidated Civil Action No. 1:00CV00183TFH. First Amendment to Consent Decree. Available at: www.epa.gov/sites/production/files/2015-05/documents/firstamendment-dcwasa-cd.pdf (accessed 6 April 2018).

EPA (2017) DC Water's environmental impact bond: A first of its kind. Available at: www.epa.gov/ sites/production/files/2017-04/documents/dc_waters_environmental_impact_bond_a_first_of_its_ kind_final2.pdf (accessed 6 April 2018).

Farmer L (2016) This government bond insures against failure. Available at: www.governing.com/ topics/finance/gov-government-bond-insures-against-failure.html (accessed 6 April 2018).

Fields D (2017) Urban struggles with financialization. Geography Compass. doi:10.1111/gec3.12334 
Goldman Sachs (2016) Fact Sheet: DC Water environmental impact bond. Available at: www. goldmansachs.com/media-relations/press-releases/current/dc-water-environmental-impact-bondfact-sheet.pdf (accessed 6 April 2018).

Halbert L and Attuyer K (2016) Introduction: The financialisation of urban production: Conditions, mediations and transformations. Urban Studies 53: 1347-1361.

Hawkins G (2016) Green infrastructure modification approved. Available at: http://georgehawkins. net/green-infrastructure-modification-approved/ (accessed 6 April 2018).

Herrera D (2017) Environmental impact bonds: Next big thing for green investments? Available at: www.edf.org/blog/2017/07/14/environmental-impact-bonds-next-big-thing-green-investments (accessed 6 April 2018).

Heynen N (2014) Urban political ecology I: The urban century. Progress in Human Geography 38: 598-604.

Heynen N, Kaika M and Swyngedouw E (2006) In the Nature of Cities: Urban Political Ecology and the Politics of Urban Metabolism. New York: Routledge.

Johnson L (2013) Catastrophe bonds and financial risk: Securing capital and rule through contingency. Geoforum 45: 30-40.

Knuth S (2016) Seeing green in San Francisco: City as resource frontier. Antipode 48: 626-644.

NRDC (2015) Comments of Rebecca Hammer, Staff Attorney, Water Program, Natural Resources Defense Council. Available at: www.dcen.net/dc/wp-content/uploads/2015/07/NRDC-et-alComments-on-Proposed-DC-Water-CD-Modification-July-2015-FINAL.pdf

O'Cleireacain C (2012) Cleaner rivers for the national capital region: Sharing the cost. Available at: www.brookings.edu/wp-content/uploads/2016/06/0523-washington-dc-clean-water-ocleireacain.pdf (accessed 6 April 2018).

RCC (2015) Comments of Matthew Fleischer, Executive Director, Rock Creek Conservancy. Available at: www.dcen.net/dc/wp-content/uploads/2015/07/DCWaterLTCPCommentsRockCreekConservancy.pdf (accessed 6 April 2018).

Sbragia A (1996) Debt Wish: Entrepreneurial Cities, US Federalism, and Economic Development. Pittsburgh: University of Pittsburgh Press.

Shandra J, McKinney L, Leckband C, et al. (2010) Debt, structural adjustment, and biodiversity loss: A cross-national analysis of threatened mammals and birds. Human Ecology Review 17: 18-33.

Swyngedouw E (1996) The city as a hybrid: On nature, society and cyborg urbanization. Capitalism Nature Socialism 7(2): 65-80.

Swyngedouw E and Heynen N (2003) Urban political ecology, justice and the politics of scale. Antipode 35: 898-918.

Ulrich M (2014) Cleaning up the capital's rivers: Solving the problem of combined sewer overflows in Washington DC. Journal of Science Policy \& Governance 4(1): 1-26.

Valderrama A (2016) Pay for performance meets green infrastructure. Available at: www.nrdc.org/ experts/alisa-valderrama/pay-performance-meets-green-infrastructure (accessed 6 April 2018).

Wachsmuth D and Angelo H (2018) Green and gray: New ideologies of nature in urban sustainability policy. Annals of the American Association of Geographers. doi: 10.1080/24694452.2017.1417819 